\title{
Implementation And Analysis High Availability Network File System Based Server Cluster
}

\author{
Chaerul Umam $^{1}$, L. Budi Handoko ${ }^{2}$, Ghulam Maulana Rizqi ${ }^{3}$ \\ ${ }_{1}^{1}$ Program Studi Teknik Informatika, Fakultas IImu Komputer, Universitas Dian Nuswantoro \\ Jl. Nakula I No. 5-11 Semarang, 50131 Telp. (024) 3517261, e-mail: chaerul@dsn.dinus.ac.id \\ ${ }^{2}$ Program Studi Teknik Informatika, Fakultas Ilmu Komputer, Universitas Dian Nuswantoro \\ Jl. Nakula I No. 5-11 Semarang, 50131 Telp. (024) 3517261, e-mail: handoko@dsn.dinus.ac.id \\ ${ }^{3}$ Program Studi Teknik Informatika, Fakultas IImu Komputer, Universitas Dian Nuswantoro \\ J. Nakula I No. 5-11 Semarang, 50131 Telp. (024) 3517261, e-mail: 111201005499@mhs.dinus.ac.id
}

\section{ARTICLE INFO}

Article history:

Received 23 July 2018

Received in revised form 30 July 2018

Accepted 3 Agustus 2018

Available online 17 Agustus 2018

\section{ABSTRACT}

Server is a computer system that provides the kind of service in a computer network. One of the functions of the server is as data storage. Computers servers with high availability values are generally referred to as High Availability (HA) Server. HA enables a server can be operational in a sustainable manner for long periods of time. Now, HA has been combined with a cluster technique known as High Availability Clusters or failover cluster. In this research the author intends to apply, analyze, and implement a network file server that has a high availability of service. Researchers used a pacemaker as cluster resource management, Corosync as cluster messaging service and DRBD for the synchronization of data if a failover occurs and measured network performer cluster file system that does have a high availability service. The result is a network file system or the availability of the cluster has a value of $99.998 \%$ availability, which means it has a High Availability. The server network file system failover cluster meets the conditions, which, if the primary server (master) dies it will be replaced by a slave server.

Keywords: Server, Cluster, High Availability, Network File System

\section{Pendahuluan}

Seiring dengan perkembangan teknologi, tuntutan akan kebutuhan informasi berupa data dalam kehidupan sehari-hari juga semakin meningkat. Server merupakan sebuah sistem komputer yang menyediakan jenis layanan dalam sebuah jaringan komputer. Salah satu layanan yang diberikan oleh server adalah layanan penyimpanan data. Server yang berfungsi dan memiliki layanan sebagai penyimpanan data biasa disebut network file sistem. Mengingat fungsi yang dimiliki server adalah memberikan layanan kepada client, maka server dituntut untuk seminimal mungkin mengalami gangguan yang dapat menggangu layanan yang diberikan kepada client[1]. Komputer-komputer server dengan nilai ketersediaan yang tinggi umumnya disebut dengan istilah High Availability Server. Dengan adanya High Availability memungkinkan sebuah server dapat beroperasional secara berkelanjutan untuk jangka waktu yang lama. Dalam perkembangannya sekarang, teknologi High Availability atau yang disingkat HA telah 
dikombinasikan dengan teknik cluster yang dikenal dengan istilah High Availability Clusters atau failover cluster[2].

Tujuan penelitian penelitian ini adalah untuk membangun network file sistem yang memiliki high availabilty. Implementasi dilakukan dengan menggunakan mekanisme clustering DRBD dan pacemaker sebagai cluster resource management agar server primary dan server secondary dapat memiliki data yang sama dan ketika terjadi failover klien tidak terpengaruh dengan perpindahan server karena datanya tetap sama. Penelitian ini juga mengukur dan menganalisis downtime ketika server master mengalami failover, throughput dan latency server, serta kecepatan sinkronisasi data.

Permasalahan yang dijadikan obyek penelitian pada penelitian ini adalah bagaimana menganalisa, mengimplementasi, dan menerapkan sistem ketersediaan tinggi atau high availability pada network file sistem berbasis cluster server, bagaimana hasil analisa high availability pada network file sistem cluster tersebut, serta bagaimana nilai availability sistem yang didapat.

\subsection{Network file sistem (NFS)}

Network file sistem (NFS) merupakan teknologi untuk berbagi sumber daya seperti file dan direktori antar perangkat melalui jaringan komputer. Dengan menggunakan NFS user dan program dapat mengakses file pada sistem remote seolah-olah mereke mengakses file lokal komputer[3].
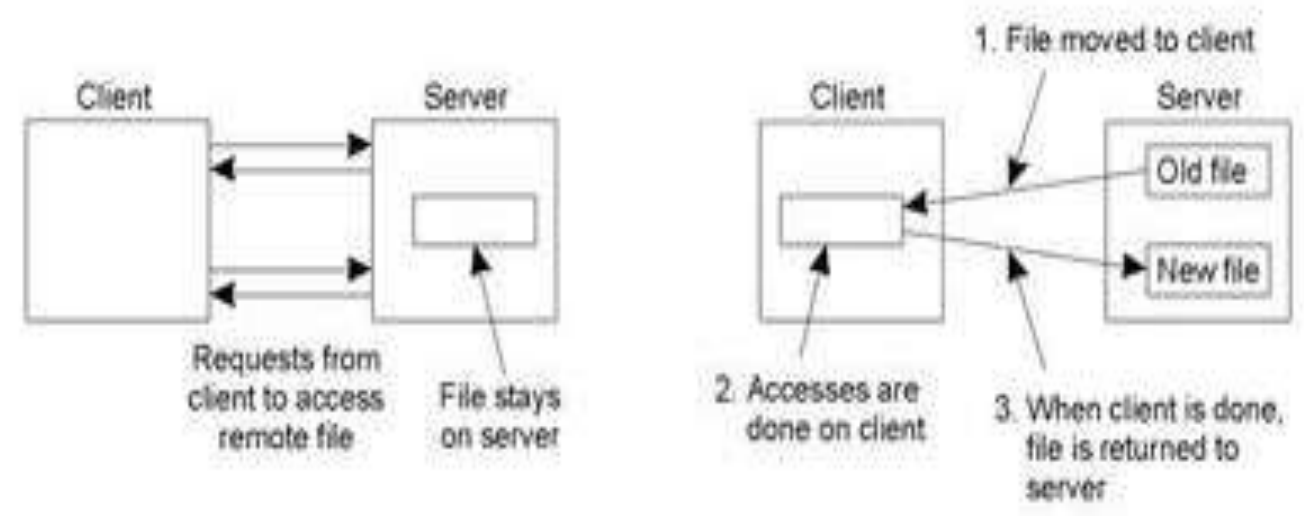

Gambar 1. Sistem Kerja NFS

\subsection{High Availability}

Storage Network Industri Assciation (SNIA) memiliki kamus online (www.snia.org/dictionary), yang mendefinisikan high availability adalah suatu kemampuan dari suatu sistem untuk melakukan fungsinya secara berkesinambungan (tanpa adanya interupsi) untuk jangka waktu lebih lama dari pada ketahanan yang di berikan oleh masing-masing komponennya. Availability biasanya di ukur berdasarkan istilah 'nine' semakin banyak nine maka semakin tinggi sebuah sistem availability. Mengapa 'nine' karena tidak mungkin mendapatkan ketersediaan sebesar seratus persen[3].

Nilai availability yang diakui cukup baik adalah 99,9999 \% (six nines), yang menunjukkan tingkat kerusakan sebesar 2,6 detik per bulan. Akan tetapi angka tersebut bukanlah standar yang baku. Untuk masalah standar yang baku tergantung dari service level agreement. Dalam kasus ini biasanya diatur didalam kebjakan pemerintah atau undang-undang di pemerintahan yang mengatur masalah regulasi. Di Indonesia diatur didalam Peraturan Mentri

TRANSFORMATIKA Vol. 16, No. 1, Juli 2018: $31-39$ 
Komunikasi dan Informatika "Tentang Standar Kualitas Pelayanan Jasa Teleponi Dasar Jaringan Tetap Mobilitas Terbatas"[10]. Mengacu pada Bab X pasal 27 prosentase availability sistem sebesar $\geq 90 \%$. Availability sistem juga dapat dirumuskan sebagai berikut:

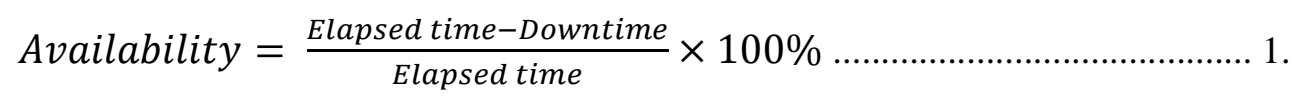

\subsection{Distributed Replicated Block Device}

DRBD merupakan singkatan dari Distributed Replicated Block Device yaitu komponen perangkat lunak berbasis linux yang memfasilitasi pengganti dari sistem penyimpanan data bersama oleh mirroring jaringan komputer. DRBD memungkinkan sistem penyimpanan data bersama untuk menjaga konsistensi data antara beberapa sistem dalam jaringan. DRBD juga memastikan layanan HA (High Availability) dalam server[6].

DRBD bisa dianalogikan sebagai mekanisme RAID-1 (mirroring, bisa juga tipe RAID lain yang menggunakan prinsip mirroring), yang melakukan duplikasi data melalui network. Duplikasi data ini dilakukan dalam mekanisme block devices, bukan dalam bentuk data mentah. Jika RAID-1 melakukan duplikasi isi dan data suatu hardisk atau partisi ke hardisk atau partisi lain, DBRD melakukan hal yang sama, hanya saja melalui network.

DRBD memiliki suatu keunggulan dibandingkan hardisk RAID, yaitu backup server berada terpisah dengan sumber backup. Pemisahan ini membawa keuntungan preventif, jika ada masalah pada salah satu server, server lainnya akan bertindak sebagai server pengganti. Jika server utama sudah kembali pulih, kendali akan dikembalikan ke server utama.

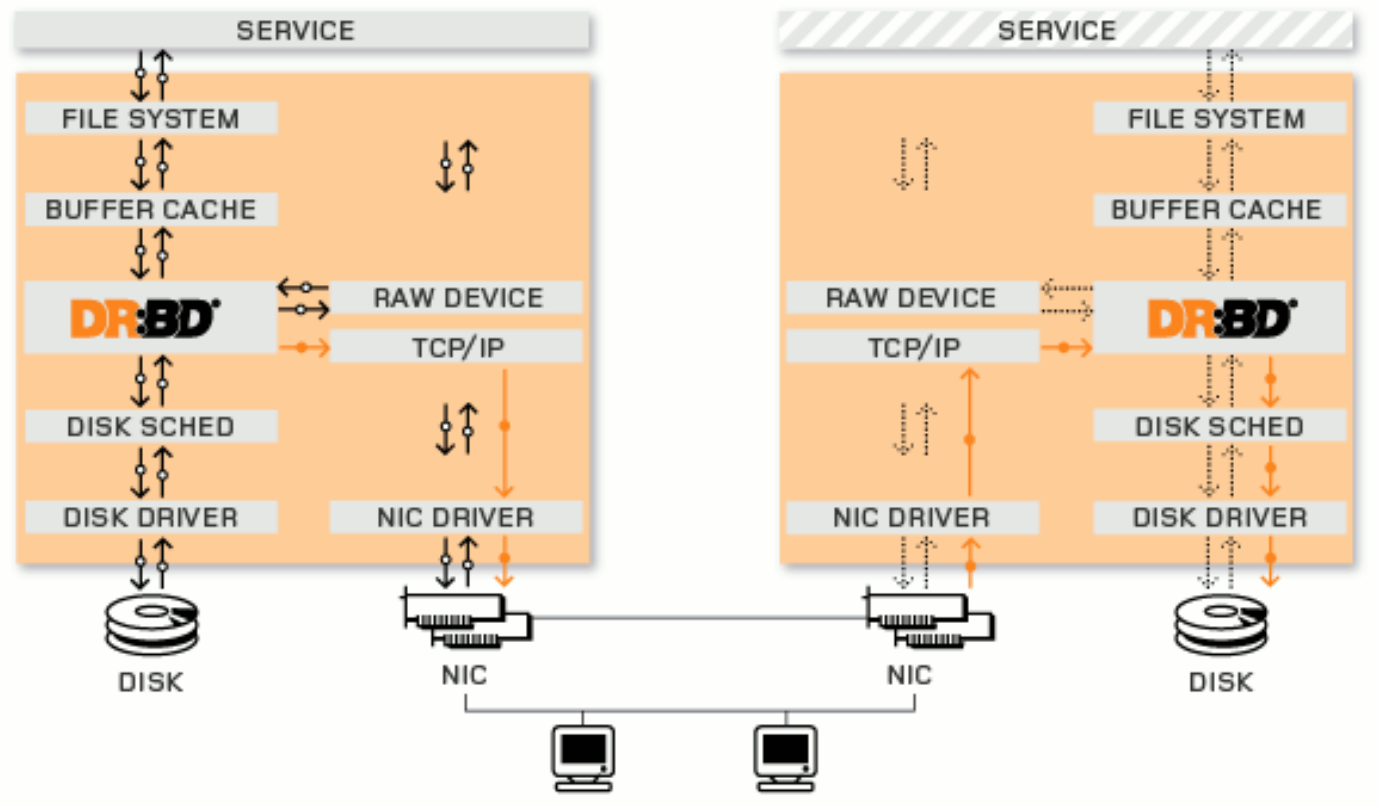

\subsection{Pacemaker}

Gambar 2. Sistem kerja DRBD

Pacemaker merupakan HA (High Availability) resource manager yang dapat digunakan untuk server cluster berskala besar ataupun kecil yang bersifat open source. Pacemaker mendukung banyak skenario deployment, dari yang paling sederhana 2-node cluster standby sampai 16-node aktif atau konfigurasi aktif. Pacemaker juga dapat secara dramatis mengurangi biaya hardware dengan memungkinkan beberapa aktif maupun pasif cluster untuk digabungkan dan berbagi node cadangan umum. Pacemaker memonitor sistem untuk kedua kegagalan antara perangkat lunak dan perangkat keras. Dalam hal kegagalan, Pacemaker secara otomatis akan memulihkan aplikasi dan pastikan itu tersedia dari salah satu mesin yang tersedia pada cluster[6]. 


\section{Metode Penelitian}

Penelitian ini menggunakan metode experimental dan menggunakan algoritma perancangan cluster komputer yang terlihat pada gambar 3 dibawah. Metode ini menerapkan percobaan penggunaan DRBD, pacemaker, dan corosync untuk implementasi high availability pada network file sistem cluster kemudian menganalisa performa dari server tersebut[6].

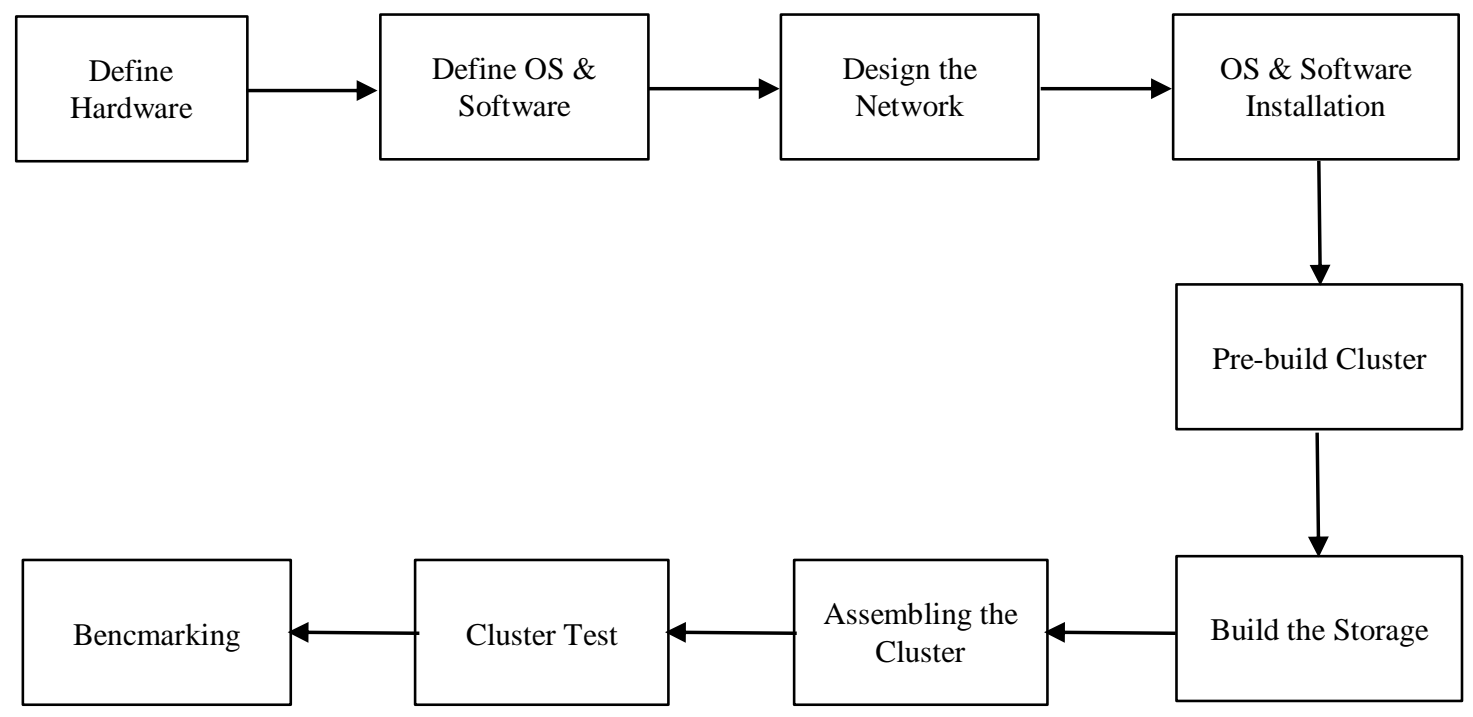

Gambar 3. Algoritma perancangan cluster komputer

\subsection{Topologi Jaringan}

Dalam perancangan sistem komputer cluster ini, terdapat 2 server dan klien yang terhubung dalam satu jaringan. Server terdiri dari server master yaitu server utama yang memberikan layanan dan server slave sebagai server backup jika terjadi failover. Server node 1 memiliki nama domain nfs1.net sedangkan untuk server node 2 memiliki nama domain nfs2.net. Gambar dibawah ini merupakan topologi jaringan yang digunakan dalam sistem komputer cluster.

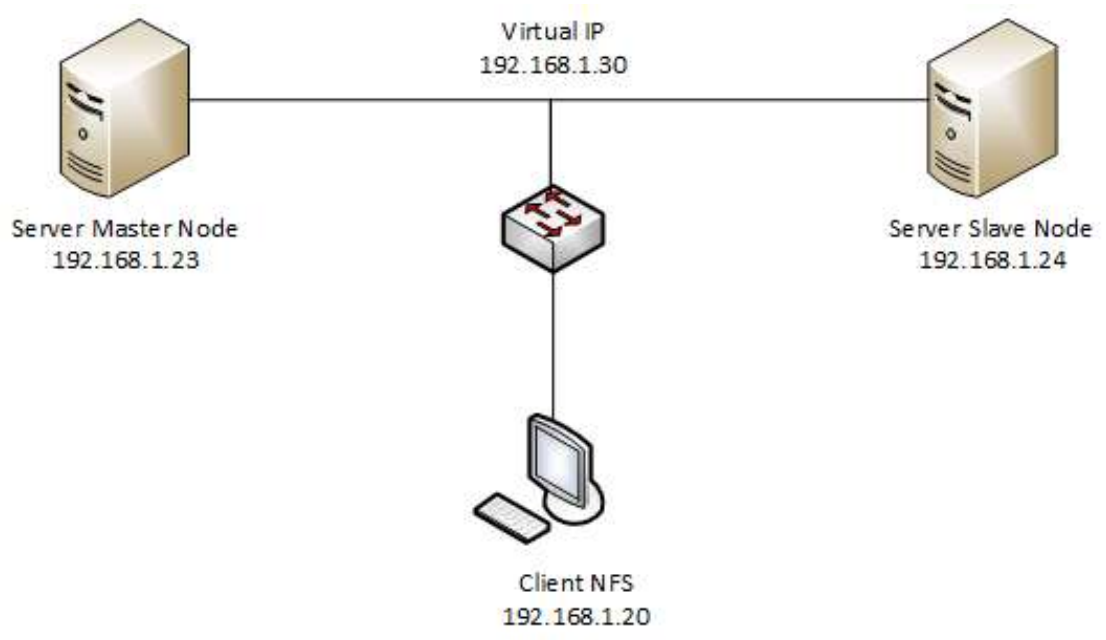

Gambar 4. Topologi jaringan

TRANSFORMATIKA Vol. 16, No. 1, Juli $2018: 31-39$ 


\subsection{Tahapan implementasi}

Tahapan implementasi yaitu :

1. Instalasi Sistem Operasi Ubuntu 12.04 LTS

2. Konfigurasi Jaringan

3. Konfigurasi DRBD

4. Konfigurasi NFS

5. Konfigurasi Pacemaker dan Corosync

6. Integrasi DRBD, NFS, dan Pacemaker

\subsection{Hasil Implementasi dan Analisa}

Gambar dibawah menunjukan status dari pacemaker yang mengambil alih semua konfigurasi atau menjadi cluster resource management.

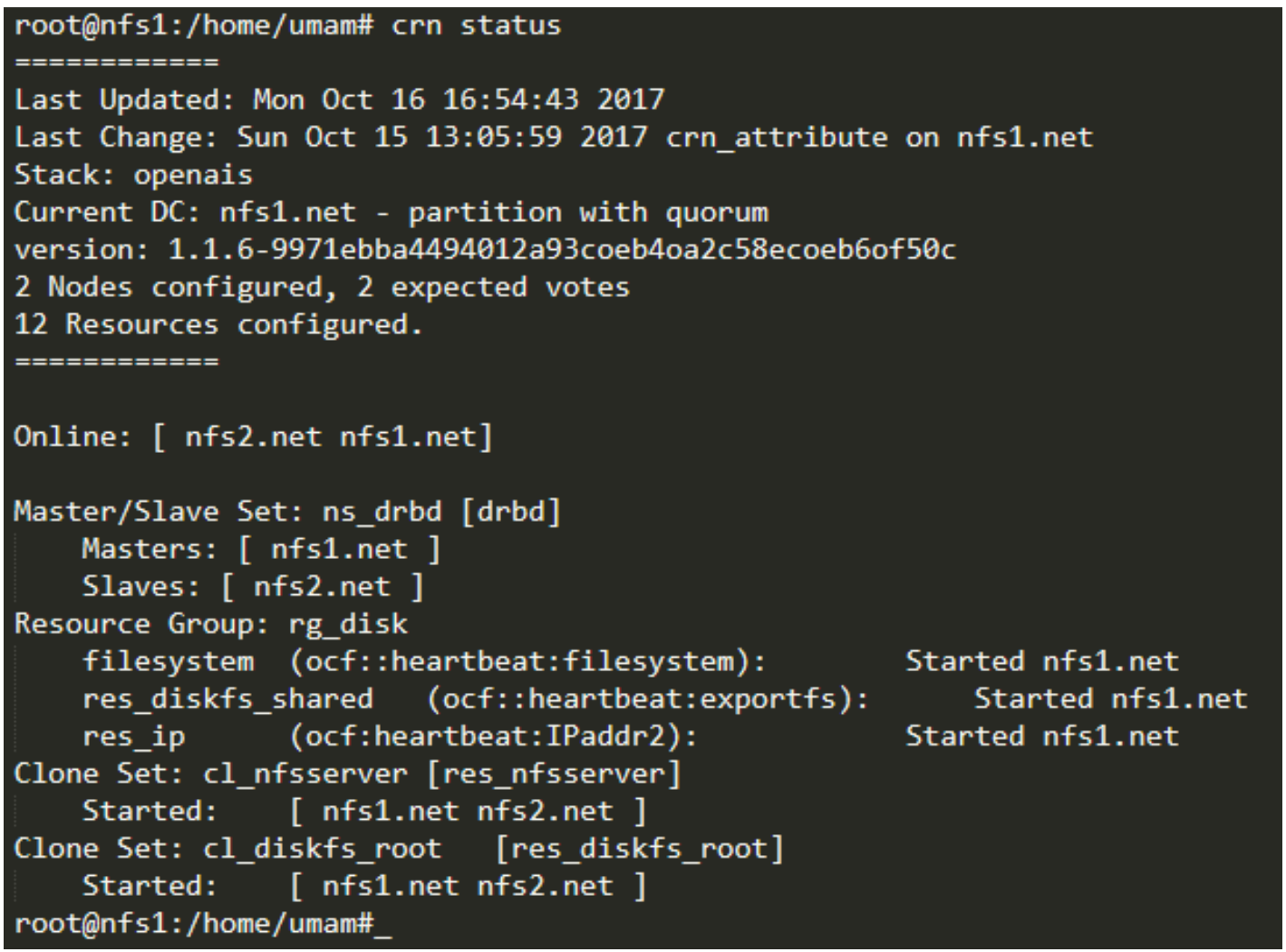

Gambar 5. Status Pacemaker, DRBD, dan NFS terintegrasi

\subsection{Pengujian dan Analisa}

Pengujian dilakukan pada beberapa parameter. Untuk parameter terdiri dari pengukuran seberapa cepat data yang sinkron, throughput dan latency, serta high availability. Pada pengukuran ini terdapat variasi pada data yang akan di tulis pada salah satu node (server).

\subsection{Sinkronisasi Data}

Pada pengujian ini mengukur kecepatan sinkronisasi data antara node 1 dengan node 2 . Pengujian dilakukan pada data berukuran 1GB, 500MB, 100MB, dan $50 \mathrm{MB}$. Tiap data diujikan sebanyak 5 kali pengujian.

\section{Hasil dan Pembahasan}




\subsection{Hasil Pengujian}

Dari pengujian yang dilakukan menghasilkan data sebagai berikut :

Tabel 1. Kecepatan sinkronisasi data 1GB

\begin{tabular}{cccc}
\hline No & Data & Waktu sinkronisasi (s) & Kecepatan sinkronisasi $(\mathbf{M B} / \mathbf{s})$ \\
\hline 1 & $1 G B$ & 14,48 & 78,40 \\
2 & $1 G B$ & 13,98 & 79,92 \\
3 & $1 G B$ & 14,79 & 78,21 \\
4 & $1 G B$ & 16,67 & 76,05 \\
5 & $1 G B$ & 15,89 & 77,23 \\
\hline
\end{tabular}

Dari tabel diatas dapat diambil kesimpulan untuk pengujian sinkronisasi data berukuran $1 \mathrm{~GB}$ sebanyak 5 kali rata-rata kecepatan sinkronisasi datanya adalah sebesar 77,96MB/s dan waktu rata-ratanya $15,16 \mathrm{~s}$.

Tabel 2. Kecepatan sinkronisasi data 500MB

\begin{tabular}{cccc}
\hline No & Data & Waktu sinkronisasi $(\mathbf{s})$ & Kecepatan sinkronisasi $(\mathbf{M B} / \mathbf{s})$ \\
\hline 1 & $500 \mathrm{MB}$ & 8,78 & 101,90 \\
2 & $500 \mathrm{MB}$ & 7,67 & 103,56 \\
3 & $500 \mathrm{MB}$ & 8,29 & 102,78 \\
4 & $500 \mathrm{MB}$ & 8,60 & 101,67 \\
5 & $500 \mathrm{MB}$ & 7,08 & 105,29 \\
\hline
\end{tabular}

Dari tabel diatas dapat diambil kesimpulan untuk pengujian sinkronisasi data berukuran 500MB sebanyak 5 kali rata-rata kecepatan sinkronisasi datanya adalah sebesar 103,04MB/s dan waktu rata-ratanya $8,084 \mathrm{~s}$.

Tabel 3. Kecepatan sinkronisasi data 100MB

\begin{tabular}{cccc}
\hline No & Data & Waktu sinkronisasi (s) & Kecepatan Sinkronisasi (MB/s) \\
\hline 1 & $100 M B$ & 1,89 & 135 \\
2 & $100 M B$ & 0,74 & 140,26 \\
3 & $100 M B$ & 1,58 & 138,01 \\
4 & $100 M B$ & 1,72 & 137,46 \\
5 & $100 M B$ & 1,72 & 137 \\
\hline
\end{tabular}

Dari tabel diatas dapat diambil kesimpulan untuk pengujian sinkronisasi data berukuran $100 \mathrm{MB}$ sebanyak 5 kali rata-rata kecepatan sinkronisasi datanya adalah sebesar $137,54 \mathrm{MB} / \mathrm{s}$ dan waktu rata-ratanya $1,53 \mathrm{~s}$.

Tabel 4. Kecepatan sinkronisasi data 50MB

\begin{tabular}{llll}
\hline No & Data & Waktu sinkronisasi $($ s) & Kecepatan Sinkronisasi $(\mathbf{M B} / \mathbf{s})$ \\
\hline 1 & $50 \mathrm{MB}$ & 0,33 & 157 \\
2 & $50 \mathrm{MB}$ & 0,49 & 156 \\
3 & $50 \mathrm{MB}$ & 0,48 & 156,40 \\
4 & $50 \mathrm{MB}$ & 0,31 & 158,96 \\
5 & $50 \mathrm{MB}$ & 0,53 & 155,20 \\
\hline
\end{tabular}

TRANSFORMATIKA Vol. 16, No. 1, Juli $2018: 31-39$ 
Dari tabel diatas dapat diambil kesimpulan untuk pengujian sinkronisasi data berukuran $50 \mathrm{MB}$ sebanyak 5 kali rata-rata kecepatan sinkronisasi datanya adalah sebesar $156,71 \mathrm{MB} / \mathrm{s}$ dan waktu rata-ratanya $0,42 \mathrm{~s}$.

Dari beberapa data di atas kita dapat menganalisa situasi yang terjadi pada high availability NFS cluster server. Semakin besar data yang disinkronkan maka semakin lama waktu sinkronisasi.

\subsection{Throughput dan Latency}

Semakin banyak jumlah file yang dikirim atau diterima maka nilai throughput dan latency akan meningkat. Hal itu dikarenakan dengan meningkatnya jumlah file yang dikirim atau maka semakin banyak juga request yang diterima oleh server sedangkan waktu pengamatannya masih sama. Berikut hasil monitoring server dengan menggunakan munin untuk throughput dan latency.

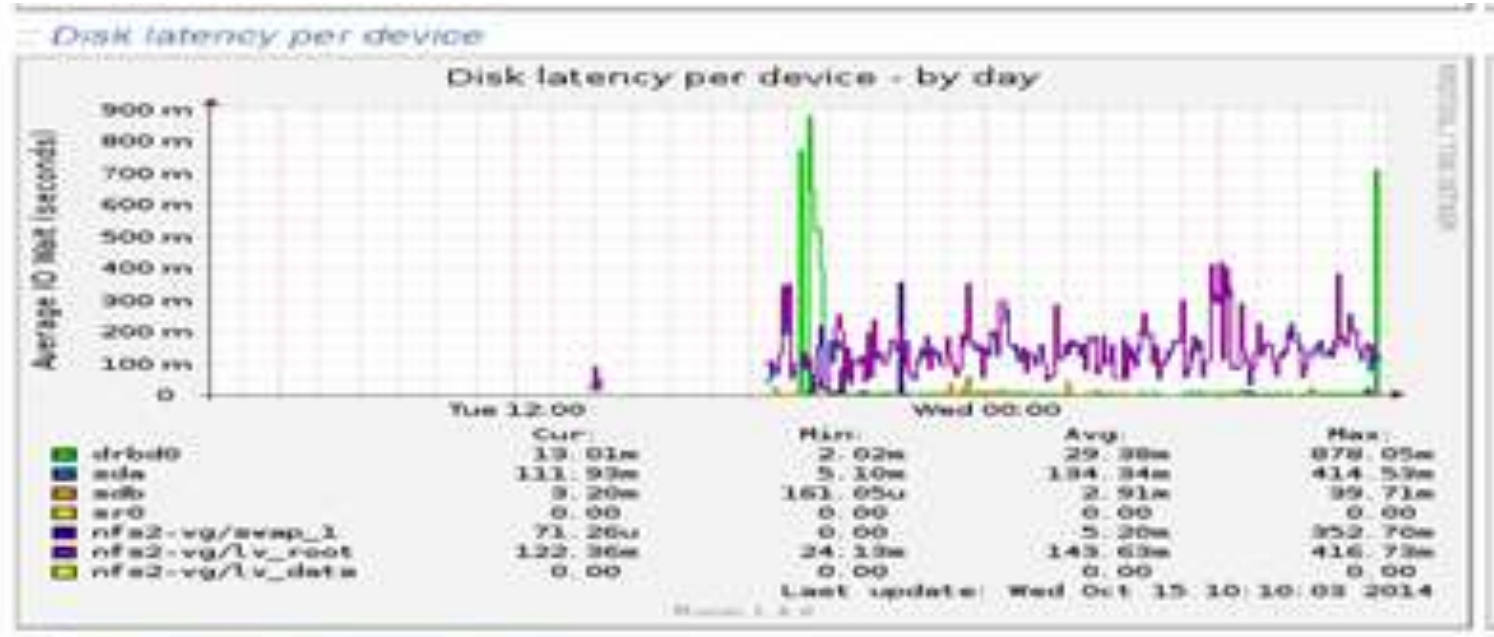

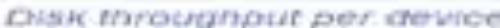

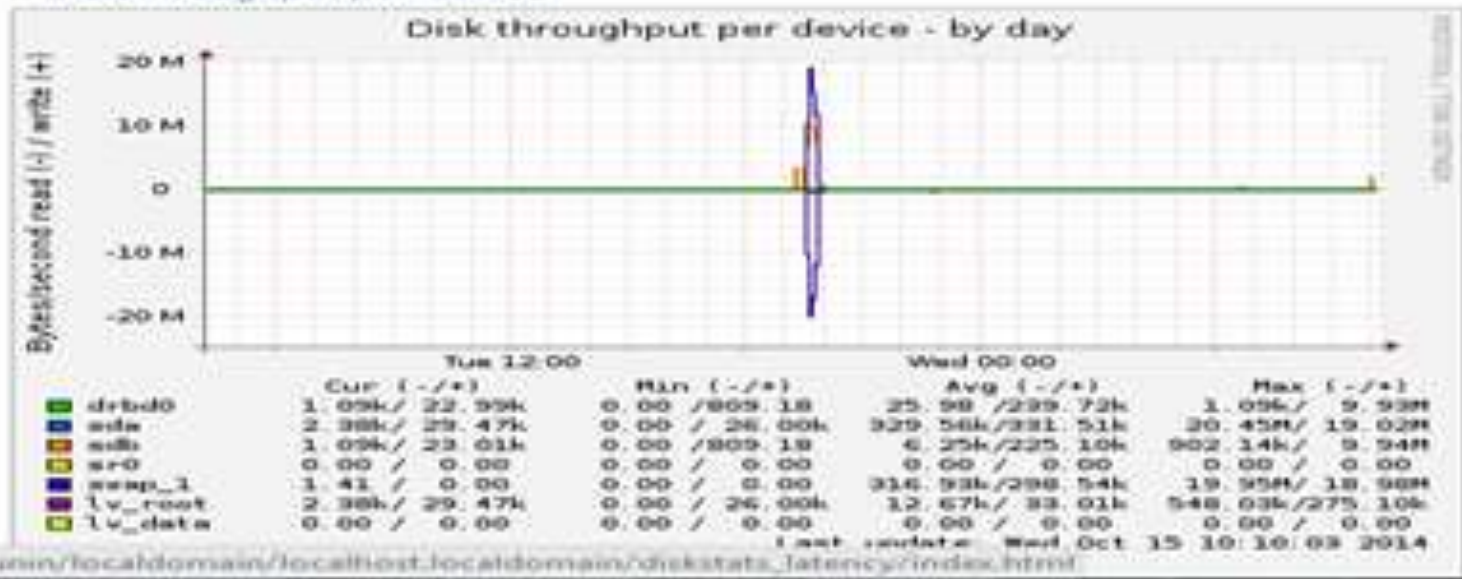

Gambar 6. Monitoring pada server master 


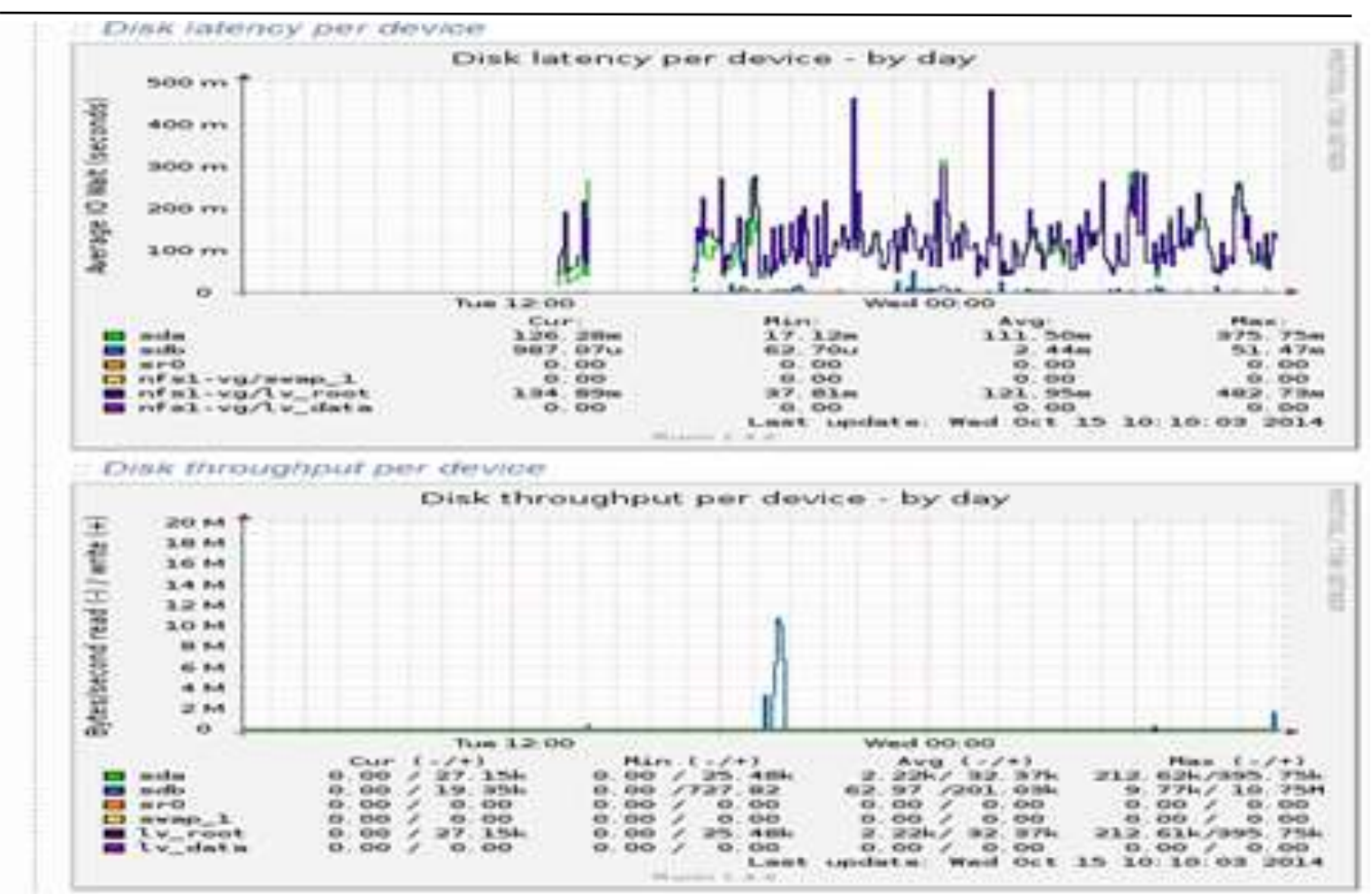

Gambar 7. Monitoring pada server slave

Dari grafik bisa dilihat pada server node master throughput dan latency lebih besar daripada server node slave. Ini dikarenakan server node master menjadi server utama yang diakses.

\subsection{High Availability}

Availability sistem dapat diukur dengan menggunakan waktu Downtime paling besar. Waktu Elapsed time diambil 6 hari, dengan mengirimkan trafik maksimum kemudian dihitung berapa kali server master mengalami down atau service dari server mengalami kegagalan. Sistem dapat diukur dengan mengambil downtime maksimal. Diketahui 6 hari adalah 518400 detik dan downtime terjadi 5 kali dan waktu untuk kembali menjadi up = 1,69 maka availability dapat dihitung

$$
\begin{gathered}
\text { Availability }=\frac{\text { Elapsed time-Downtime }}{\text { Elapsed time }} \times 100 \% \ldots \ldots \ldots \ldots \ldots \\
\text { Availability }=\frac{518400-(1,69 \times 5)}{518400} \times 100 \%=99,998 \%
\end{gathered}
$$

Hasil dari penghitungan availability adalah $=99,998 \%$ berarti NFS cluster server tersebut memiliki layanan high availability atau ketersediaan tinggi.

TRANSFORMATIKA Vol. 16, No. 1, Juli 2018: $31-39$ 


\section{Kesimpulan} berikut:

Berdasarkan penelitian yang dilakukan, maka dapat disimpulkan beberapa hal sebagai

1. Dari beberapa pengujian data yang berbeda ukuran pada sinkronisasi data menunjukan semakin besar data yang disinkronisasi maka semakin besar waktu untuk mensinkron data tersebut

2. Sistem terdiri dari dua node yaitu node pertama sebagai node master dan node kedua sebagai node slave.

3. Sistem dapat menangani failover yaitu apabila server node master mengalami down, maka server node slave akan menjadi server node master.

4. Hasil pengujian pada High Availability memiliki akurasi $99 \%$.

5. Pacemaker digunakan sebagai cluster resource management

6. Pada server node master throughput dan latency lebih besar daripada server node slave. Ini dikarenakan server node master menjadi server utama yang diakses.

7. Semakin besar data yang dirubah semakin lama waktu sinkronisasi antar node.

8. DRDB adalah aplikasi untuk sinkronisasi data pada level block device yang bekerja dibawah sistem dan dapat dikatakan tidak mengganggu sistem apabila layanan sedang berjalan.

\section{Referensi}

[1] M. B. Jan Bergstram, HANDBOOK OF NETWORK AND SYSTEM

ADMINISTRATION, Amsterdam: Elsevier, 2007.

[2] T. T.T.Lwin, "High Availability Cluster System fo Local Disaster Recovery with Markov Modelling Approach," International Journal of Computer Science, vol. 6, no. 2, pp. 25-32, 2009.

[3] K. Krooper, The Linux Enterprise Cluster: Build a Highly Available Cluster with Commodity Hardware and Free Software, San Francisco: No Strach Press, 2005.

[4] J.-G. K. Si-Choon Noh, "A High Availability Clustering and Load Balancing Mechanism for Information Security Infrastructure System," International Conference and Hybrid Information Technology, pp. 502-507, 2009.

[5] H. S. Supeno Djamali, "Power Optimization in High Availability Server Clusters," in The Proccedings of The 7th ICTS, Bali, 2013.

[6] G. H. Yihan Wu, "Model-based High Availability Configuration Framework for Cloud," ACM, 2013.

[7] Wagito, Jaringan Komputer, Teori dan Implementasi Berbasis Linux, Yogyakarta: Gaya Media, 2007.

[8] C. Bookman, Linux Clustering: Building and Maintaining Linux Clusters, New Riders Publishing, 2003.

[9] A. Sofyan, Server Linux : Membangun Linux sebagai Internet/Intranet Server, Jakarta: Nurul Fikri Computer \& Statistics, 2000.

[10] B. R. S. A. A. Bambang T.H Wilfridus, Linux System Administrator, Bandung: Informatika, 2008.

[11] I. Rijayana, "Teknologi Load Balancing Untuk Mengatasi Beban Server," Jurnal SNATI, 2005.

[12] T. Bourke, Server Load Balancing, USA: O’Reilly, 2001. 